\title{
Direct comparison of efficiency and stability of gene transfer into the mammalian heart using adeno-associated virus versus adenovirus vectors
}

Danny Chu, MDa

Christopher C. Sullivan, $\mathrm{MS}^{\mathrm{a}}$

Matthew D. Weitzman, PhD ${ }^{\text {b }}$

Lingling $\mathrm{Du}, \mathrm{MD}^{\mathrm{a}}$

Paul L. Wolf, MD

Stuart W. Jamieson, MB, FRCS ${ }^{a}$

Patricia A. Thistlethwaite, MD, $\mathrm{PhD}^{\mathrm{a}}$
From the Division of Cardiothoracic Surgery, ${ }^{a}$ University of California at San Diego, San Diego, Calif, the Salk Institute for Biological Studies, ${ }^{\mathrm{b}}$ and the Department of Pathology, ${ }^{\mathrm{c}}$ Veterans Administration Medical Center, La Jolla, Calif.

Supported by a Charles B. Wang Foundation research grant.

Received for publication March 5, 2002; revisions requested Aug 19, 2002; revisions received Oct 11, 2002; accepted for publication Dec 4, 2002.

Address for reprints: Patricia A. Thistlethwaite, MD, PhD, University of California at San Diego, Division of Cardiothoracic Surgery, 200 West Arbor Dr, San Diego, CA 92103-8892 (E-mail: pthistlethwaite@ ucsd.edu)

J Thorac Cardiovasc Surg 2003;126:671-9

Copyright $\odot 2003$ by The American Association for Thoracic Surgery

$0022-5223 / 2003 \$ 30.00+0$

doi:10.1016/S0022-5223(03)00082-5
Objective: Recent gene therapy strategies have relied on the use of adenovirus or plasmid as vehicles for gene delivery to the heart. These approaches have been limited by low transduction frequencies and transient transgene expression. We sought to determine whether adeno-associated virus produces more stable, higher efficiency gene expression in the rodent heart than did previous conventional methods.

Methods: Two recombinant viral constructs were made: an adeno-associated virus containing the lac $Z$ gene under the control of the cytomegalovirus promoter (AAVlacZ) and an adenovirus expressing lac $Z$ under the control of the same promoter (Adeno-lacZ). Twenty rats were injected (into the ventricular apex) with $1 \times 10^{7-8}$ genomic particles of each virus. Animals were put to death at serial time points and transgene expression quantitated by $\beta$-galactosidase activity, myocardial staining, and Western blot protein analysis.

Results: Three months after adeno-associated virus gene transfer, animals demonstrated stable $\beta$-galactosidase expression in $60 \%$ of cardiomyocytes without evidence of myocardial inflammation/necrosis. The distribution and degree of protein expression and number of positive cells at 3 months were equivalent to transgene expression at 4 weeks. Adeno-associated virus was not detected in organs other than the heart. In contrast, Adeno-lacZ animals displayed transient $\beta$-galactosidase activity in $60 \%$ of cardiomyocytes, which was undetectable 4 weeks after gene transfer. Adenovirus-treated animals manifest significant myocardial inflammation and had transgene expression in other organs.

Conclusion: Direct intramyocardial injection of an adeno-associated virus vector programs stable, long-term, cardiac-specific transgene expression in the rodent heart for up to 3 months. Our results suggest adeno-associated virus has significant advantages for long-term transgene expression in the heart compared to adenovirus vectors.

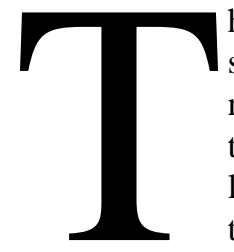

he transfer of genes into the heart, resulting in the expression of select proteins, is a promising research tool and potential therapy for numerous cardiovascular diseases including ischemic cardiomyopathy, arrhythmia, and congestive heart failure. The utopian vector for long-term myocardial gene therapy would effect stable, efficient transduction of myocytes in vivo with any transgene, without causing toxicity or unwanted side effects. Most gene therapy experiments in the heart 
have focused on 3 main vector types: plasmid or naked fragment DNA, ${ }^{1}$ viral vectors (adenovirus-based systems, ${ }^{2}$ retroviruses, ${ }^{3}$ herpes viruses, ${ }^{4}$ and hybrid/gutless viruses ${ }^{5}$ ), and cationic liposomes. ${ }^{6}$ The choice of which vector system to use for sustained, highly efficient gene transfer remains controversial.

In recent years, adenovirus has been the vector used in early human gene therapy trials for the treatment of ischemic cardiomyopathy, either as a sole modality or in conjunction with coronary artery bypass surgery. ${ }^{7,8}$ In animals, adenovirus vectors have been used for gene delivery into myocardium by direct intramuscular injection or via infusion of virus into the coronary arteries. ${ }^{9}$ These studies have demonstrated several limitations to adenovirus as a gene delivery tool for sustained transgene expression. First, transgene expression is transient, peaking between 24 hours and 7 days and retained for only 2 to 3 weeks; second, a significant cytotoxic, cell-mediated immune response is observed. The transient expression of transgene in adenoviral gene transfer is considered to be due to both an unstable episomal feature of the introduced DNA and the expression of viral proteins that elicit immunologic elimination of transduced cells via a CD8+ lymphocyte-mediated cell lysis. $^{10}$

Adeno-associated virus (AAV) vectors represent an alternative approach to cardiovascular gene therapy. These viruses contain no viral protein-coding sequences to stimulate an immune response, have the ability to integrate into the genome of the host, and do not require active cell division for expression to occur. ${ }^{11}$ This unique profile of biologic properties has allowed AAV to program efficient and stable recombinant gene expression in liver, ${ }^{12}$ skeletal muscle,${ }^{13}$ retina, ${ }^{14}$ and brain ${ }^{15}$ in both rodents and primates. Recent reports have shown that AAV can transduce cardiomyocytes in vitro and in vivo. ${ }^{16-18}$ However, these studies demonstrated that the efficiency of AAV-mediated transgene expression in the heart was low (approximately $0.2 \%$ $1.0 \%$ ). Although results have been published about both $\mathrm{AAV}$ and conventional adenovirus, there are no long-term direct comparisons of these vectors in an in vivo cardiovascular model under uniform conditions.

The goal of this study was to compare directly adenovirus and AAV with respect to relative efficiency, toxicity, and duration of expression after gene delivery by intramyocardial injection in a rodent model. This study defines a comparative analysis of spatial and temporal expression using these 2 viral vectors and serves as groundwork for optimizing the kinetics and longevity of genes introduced into the mammalian heart by direct injection. Our results suggest that AAV vectors may be useful for sustained, long-term gene expression in the heart without inducing inflammation or immunologic response.

\section{Materials and Methods}

\section{Viral Plasmid and Vector Production}

Adenovirus vector containing lacZ gene was based on the Ad5 backbone with E1 and E3 deletions. The lacZ gene was subcloned into the adenoviral shuttle plasmid pShuttle-CMV (driven by cytomegalovirus promoter/enhancer) between $\mathrm{XhoI}$ and HindIII restriction enzyme sites in the multiple cloning site. The resulting plasmid, pShuttle-CMV-lacZ, was cotransfected with pAdEasy-1 (plasmid containing Ad5 genome with E1/E3 deletion) into 293 cells using the X-tremeGENE reagent (F. Hoffmann-La Roche Ltd, Basel, Switzerland) to generate recombinant adenovirus containing the lac $Z$ gene. Large-scale adenovirus vector preparation was performed as described previously, using $\mathrm{CsCl}_{2}$ density purification and dialysis. ${ }^{19}$ Genomic adenoviral titers were determined by spectrophotometric analysis of virus particle DNA. Adenoviral stocks were tested for levels of replication-competent adenovirus (RCA) by assessing cytopathic effects of our preparations on human umbilical vein endothelial cells (HUVEC). We found negligible $\left(<1 \times 10^{7}\right)$ cytopathic effects, confirming lack of contamination of our virus preparations with RCA.

Two cotransfection plasmids, pXX2 and pXX6, were used for AAV vector production. $\mathrm{pXX} 2$ contains the AAV rep and cap genes, while pXX6 has the adenoviral gene products that are required to facilitate AAV replication. ${ }^{20}$ The pAAV-lacZ was created by inserting lac $Z$ into the pAAV-shuttle vector generated in our laboratory via standard subcloning techniques. This shuttle vector has two inverted terminal repeats (ITRs) required for AAV production, cytomegalovirus (CMV) promoter/enhancer, multiple cloning site, and a simian virus 40 (SV40) polyadenylation tail signal. The lac $Z$ gene was inserted into the multiple cloning site of the pAAV-shuttle vector between XhoI and HindIII restriction enzyme sites.

A large quantity of recombinant AAV serotype 2 containing the lacZ gene (AAV-lacZ) was produced and purified in our laboratory by cotransfecting low passage 293T cells. Triple cotransfections with pXX2, pXX6, and pAAV-lacZ plasmids were accomplished with Polyfect Transfecting Reagent (Qiagen, Valencia, Calif) when 293 T cells were $80 \%$ to $90 \%$ confluent. Subsequently, the transfected $293 \mathrm{~T}$ cells from $1015-\mathrm{cm}$ plates were incubated at $37^{\circ} \mathrm{C}$ and supplemented with fresh Dulbecco's modified Eagle's medium (DMEM) with $10 \%$ fetal bovine serum (FBS) growth media daily for 72 total hours. Cells collected in phosphatebuffered saline solution (PBS) were centrifuged at $1000 \mathrm{~g}$ at room temperature for 15 minutes. Cell pellets were redissolved in $25 \mathrm{~mL}$ of DMEM and underwent 2 cycles of freeze/thaw at $-80^{\circ} \mathrm{C}$ and $37^{\circ} \mathrm{C}$, respectively, with vigorous vortexing to lyse the cells. Benzonase (Sigma-Aldrich, St. Louis, Mo) was added to the mixture for a final concentration of $50 \mathrm{U} / \mathrm{mL}$ to eliminate unpackaged DNA. Cellular debris was separated from the cleared cell lysate via centrifugation at $3000 \mathrm{~g}$ at room temperature for 15 minutes. Deoxycholic acid (Sigma-Aldrich), which helps AAV to bind the heparin column, was added to the clear cell lysate for a final concentration of $0.5 \%$ and incubated at $37^{\circ} \mathrm{C}$ for 30 minutes. Cell lysates were consecutively filtered through $5-\mu \mathrm{m}$ and $0.8-\mu \mathrm{m}$ filters (Millipore, San Jose, Calif). The lysates were then centrifuged at $9500 \mathrm{~g}$ at $4^{\circ} \mathrm{C}$ for 10 minutes to further eliminate any remaining particulates. 
AAV-lacZ high-grade purification was based on the singlestep, gravity-flow column technique described by Auricchio and colleagues. ${ }^{21}$ Type I heparin columns (Sigma-Aldrich) were equilibrated with 5 column volumes of $\mathrm{PBS} / 1 \mathrm{mmol} / \mathrm{L} \mathrm{MgCl}_{2}$ at a rate of $0.5 \mathrm{~mL} / \mathrm{min}$ using an Econo-Pump (Bio-Rad, Hercules, Calif). The cleared cell lysate was added directly to the column with a flow rate of $0.2 \mathrm{~mL} / \mathrm{min}$. The column was subsequently washed with 5 column volumes of PBS/ $1 \mathrm{mmol} / \mathrm{L} \mathrm{MgCl} / 2 / 0.1 \mathrm{~mol} / \mathrm{L} \mathrm{NaCl}$ at a rate of $0.5 \mathrm{~mL} / \mathrm{min}$. The virus was eluted with $6 \mathrm{~mL} \mathrm{PBS} / 1$ $\mathrm{mmol} / \mathrm{L} \mathrm{MgCl} 2 / 0.4 \mathrm{~mol} / \mathrm{L} \mathrm{NaCl}$ at a rate of $0.5 \mathrm{~mL} / \mathrm{min}$. The first $1.5-\mathrm{mL}$ volume of flow-through was discarded. The next $4 \mathrm{~mL}$ of flow-through was collected in $1-\mathrm{mL}$ fractions. The concentration of the AAV-lacZ was determined by real-time polymerase chain reaction (7700 Sequence Detector, Applied Biosystems, Foster City, Calif) with an SYBR Green detection kit (Applied Biosystems). The viral preparation was desalted by dialyzing the preparation against $2 \mathrm{~L} \mathrm{PBS} / 1 \mathrm{mmol} / \mathrm{L} \mathrm{MgCl}_{2}$ at $4{ }^{\circ} \mathrm{C}$ twice and, subsequently, sterile-filtered through a $0.2-\mu \mathrm{m}$ filter (Millipore). All viral preparations had at least $1 \times 10^{11}$ genomic particles per milliliter. The purified vectors were then retested for their transgene expression by infecting 293 cells.

\section{Gene Transfer Protocol Into Rat Hearts in Vivo}

Fischer rats (12-14 weeks old; Harlan, San Diego, Calif) were anesthetized with intraperitoneal ketamine $(50 \mathrm{mg} / \mathrm{kg})$ and xylazine $(10 \mathrm{mg} / \mathrm{kg})$. The animals were intubated with a 14-gauge, $2.54-\mathrm{cm}$ angiocatheter under direct vision and ventilated with a Harvard rodent ventilator model 683 (Harvard Apparatus, Holliston, Mass) with minute ventilation of $150 \mathrm{~mL} / \mathrm{min}$. The heart was exposed via a left anterolateral thoracotomy incision at the fourth intercostal space. Next, $2 \times 10^{8}$ genomic particles of AAV-lacZ in $200 \mu \mathrm{PBS} / 1 \mathrm{mmol} / \mathrm{L} \mathrm{MgCl}_{2}$ were injected intramyocardially into the left apex of the heart divided into 3 separate injections covering an area of approximately $0.75 \mathrm{~cm}^{2}$ in each of 16 rats in the AAV-lacZ group; $2 \times 10^{7}$ genomic particles of Adeno-lacZ in 200 $\mu \mathrm{PBS} / 1 \mathrm{mmol} / \mathrm{L} \mathrm{MgCl}_{2}$ were injected in a similar fashion into the hearts of 16 rats in the Adeno-lacZ group. Injections were performed with a 27 -gauge needle. Absence of blood with syringe aspiration and blanching of the myocardium during injection of the virus confirmed successful intramyocardial delivery of viral vectors. Negative intrapleural pressure was re-established by evacuation of air out of the chest by small tube syringe aspiration before chest closure.

At the completion of the procedure, atipamezole $(2.5 \mathrm{mg} / \mathrm{kg}$; Animal Health, Exton, $\mathrm{Pa}$ ) was injected intraperitoneally to reverse anesthetic effects. The endotracheal angiocatheter was removed after voluntary respiratory efforts were evident. A single investigator performed all the rodent operations. The mortality for gene transfer surgery was $7.7 \%$ or 4 of 64 animals (1 rodent in the AAV-lacZ group, 2 animals in the Adeno-lacZ group, and 1 rodent in the PBS group). Death occurred during surgery due to traumatic intubation or anesthetic overdose in 2 animals, while death occurred 24 to 48 hours after surgery in 2 animals. The surviving animals ( $\mathrm{n}=4$ for each group at each time point) were put to death at 36 hours, 7 days, 1 month, 3 months, and 5 months after gene delivery with intraperitoneal pentobarbital. All animals were cared for and put to death in accordance with the National Institutes of
Health's Guide for the Care and Use of Laboratory Animals (NIH Publication Vol. 25, No. 28, revised 1996).

\section{X-gal Staining and Histologic Analysis}

After explant, whole hearts were rinsed 3 times with PBS and fixed overnight at $4^{\circ} \mathrm{C}$ in $4 \%$ paraldehyde. Cardiomyocytes expressing enzymatically active $\beta$-galactosidase $(\beta$-gal) were detected by 24-hour incubation of whole hearts at $37^{\circ} \mathrm{C}$ with the chromogenic substrate $\mathrm{X}$-gal (5-bromo-4-chloro-3-indolyl- $\beta$-D-galactoside), which yields an insoluble blue precipitate when cleaved. Gross sections were photographed with a Kodak professional DCS300 digital camera (Eastman Kodak, Rochester, NY) with a macrophoto lens at $2 \times$ magnification.

A second cohort of hearts from each time point was stained with X-gal as described above, fixed in $10 \%$ formalin, embedded in paraffin, and sectioned at $10 \mu \mathrm{m}$ thickness. Hematoxylin and eosin (H \& E) staining was performed on these sections for histologic analysis. The hearts were sectioned perpendicular to their long axis. From the apical paraffin blocks, 10 short axis sections were taken at $1-\mathrm{mm}$ intervals to incorporate the distal 1.0 $\mathrm{cm}$ of the heart from base to apex. Usually the lower middle sections incorporated the needle tracks. Each heart section contained between 1500 and 3000 myocytes. Positive X-gal staining cells were counted in each section. The mean number of positive cells from each heart within each group was then reported as the percentage of positive cells in relation to the total number of myocytes counted. Photographs were taken with a fixed angle to the histologic slides using an Olympus U-DO microscope with built-in DVC-1300C digital camera (Olympus Optical, Tokyo, Japan) at $20 \times$ magnification.

\section{Western Blot Analysis and $\boldsymbol{\beta}$-Galactosidase Activity Assay}

Protein extraction and Western blots were performed as previously described $^{22}$ with $40 \mu \mathrm{g}$ of total protein isolated from the area of gene injection in each heart sample and a monoclonal anti- $\beta$ galactosidase antibody (Promega, Madison, Wis) followed by NBT/BCIP (Promega) substrate development. To test for $\beta$-gal activity, $100 \mu \mathrm{g}$ protein from each heart sample was added to 800 $\mu \mathrm{g} o$-nitrophenyl- $\beta$-D-galactose (ONPG) substrate in $1 \mathrm{ml}$ of PM-2 buffer $\left(23 \mathrm{mmol} / \mathrm{L} \mathrm{NaH} \mathrm{PO}_{4}, 77 \mathrm{mmol} / \mathrm{L} \mathrm{Na}_{2} \mathrm{HPO}_{4}, 0.1 \mathrm{mmol} / \mathrm{L}\right.$ $\mathrm{MnCl}_{2}, 2 \mathrm{mmol} / \mathrm{L} \mathrm{MgSO}_{4}, 40 \mathrm{mmol} / \mathrm{L} \beta$-mercaptoethanol, $\mathrm{pH}$ 7.3) at $37^{\circ} \mathrm{C}$ for 30 minutes. The reaction was stopped by adding 500 $\mu \mathrm{l}$ of $1 \mathrm{~mol} / \mathrm{L} \mathrm{Na}_{2} \mathrm{CO}_{3}$. Beta-gal activity was directly proportional to the color intensity of the enzymatic reaction measured at 420 $\mathrm{nm}$. Absorbance at $420 \mathrm{~nm}$ was measured by spectrophotometer (Ultraspec II, Biochrom, Cambridge, United Kingdom).

\section{Statistical Analysis}

Values for the $\beta$-gal activity assay were expressed as the mean \pm SEM. Continuous variables were compared by the Student $t$ test.

\section{Results}

Comparison of the Stability and Efficiency of Transduction of AAV and Adenovirus Vectors in the Myocardium

AAV-lacZ and Adeno-lacZ vectors were each injected into the ventricular apical myocardium of 20 immunocompetent 


\section{Adeno AAV}

\section{6 hours}
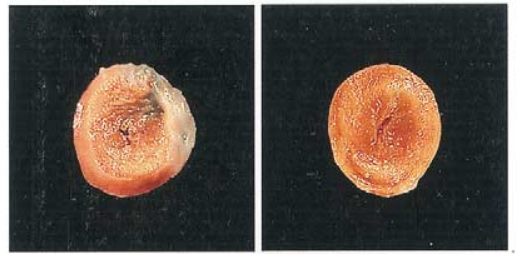

7 days
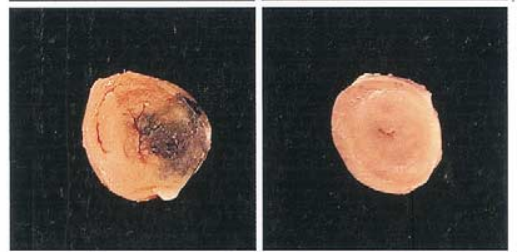

1 month
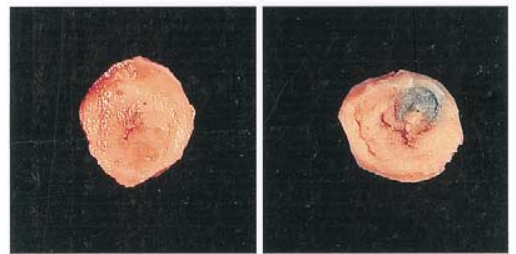

\section{3 months}
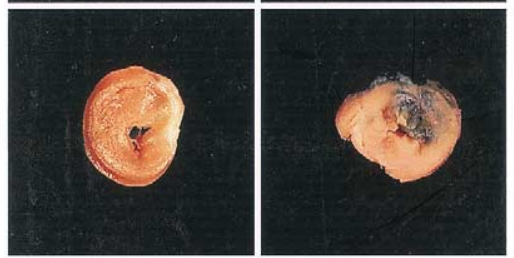

5 months
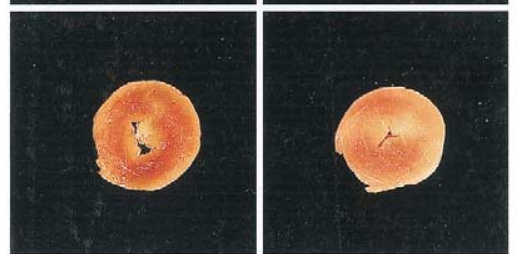

Figure 1. Gross photographs of rat hearts cut axially at various time points after gene delivery (X-gal stained for 24 hours, magnification $\times 2$ ). Adeno, Adeno-lacZ-injected hearts; AAV, AAVlacZ-injected hearts.

Fischer rats (12-14 weeks old) via a left thoracotomy approach. Sham-injected hearts were inoculated with an equal volume of $\mathrm{PBS} / 1 \mathrm{mmol} / \mathrm{L} \mathrm{MgCl}_{2}$ (the carrier solution for viral injections). The hearts were collected 36 hours, 7 days, 1 month, 3 months, and 5 months after viral inoculation; four hearts were collected at each time point for both viral groups and the sham-injected group. $\beta$-gal expression in the myocardial tissue was assayed by X-gal staining.

As shown in Figure 1, a significant difference in temporal expression of the transduced lac $Z$ gene in the heart was found. For animals infected with the adenovirus vector, $\beta$-gal expression was detected at the area of injection in gross heart specimens at 36 hours and 7 days after the gene transfer and was not detected at any subsequent time points. In contrast, $\mathrm{AAV}$-injected hearts showed $\beta$-gal expression beginning 1 month after gene transduction and continuing up to 3 months after gene transfer. Transgene expression was lost by 5 months after myocardial gene delivery. Gross myocardial staining at 1 month in the AAV-lacZ-transduced hearts was similar to the amount of staining seen at 3 months, suggesting that transgene expression was persistent without dimunition over this long interval. This result contrasts to the short time interval of less than 1 month seen for transgene expression in the heart using an adenovirus vector.

$\mathrm{X}$-gal staining for both the adenovirus and AAV groups was limited to an area of $1.0 \mathrm{~cm}^{2}$ around the injection sites and was transmural in distribution. The majority of $\beta$-galpositive cells in both groups were cardiomyocytes, as identified by light microscopy. Adenovirus delivery of transgene resulted in X-gal staining of both cardiomyocytes and macrophages, while AAV delivery of transgene resulted in $\mathrm{X}$-gal staining of cardiomyocytes only. Approximately $60 \%$ of cardiomyocytes within an area of $0.75 \mathrm{~cm}^{2}$ around the injection stained positive for $\beta$-gal for both adenovirus and AAV groups, whereas only $10 \%$ of cardiomyocytes $(0.75-$ $1.0 \mathrm{~cm}^{2}$ from the injection) stained positive in both viral groups. We, therefore, found no difference in the spatial distribution of AAV or adenovirus gene expression in the heart using the direct injection approach.

To compare directly the efficiency and stability of AAVmediated gene transfer with that of adenovirus, we injected adult Fischer rat hearts with either AAV-lacZ or AdenolacZ and quantitatively assayed them for $\beta$-gal by Western blot analysis and $\beta$-gal activity by enzymatic assay at different times after injection (Figures 2 and 3). Consistent with previous reports, ${ }^{9}$ direct intramyocardial injection of Adeno-lacZ resulted in transient transgene expression, with peak levels of $\beta$-gal and peak levels of $\beta$-gal activity measured 36 hours to 7 days after injection. By 4 weeks after myocardial transfer, transgene expression at the protein level was undetectable in the Adeno-lacZ-injected hearts. In contrast, $\beta$-gal activity in the hearts injected with AAVlacZ was first detected 1 month after gene transfer and continued at a consistent level for up to 3 months. Peak levels of $\beta$-gal activity in the AAV-lacZ-injected hearts were approximately $70 \%$ of those seen with Adeno-lacZ (Figure 3). Similarly, by Western blot analysis, $\beta$-gal was present in the hearts of animals injected with the AAV construct for up to 3 months after injection. The levels of $\beta$-gal protein measured were similar between the adenovirus- and AAV-injected myocardium.

\section{Tissue Specificity of Transgene Expression: \\ Comparison of AAV and Adenovirus}

Direct myocardial injection of AAV-lacZ resulted in transgene protein ( $\beta$-gal protein) expression in the heart alone (Figure 4). This finding suggests that AAV gene constructs can be targeted directly to myocardial tissue, without spill- 


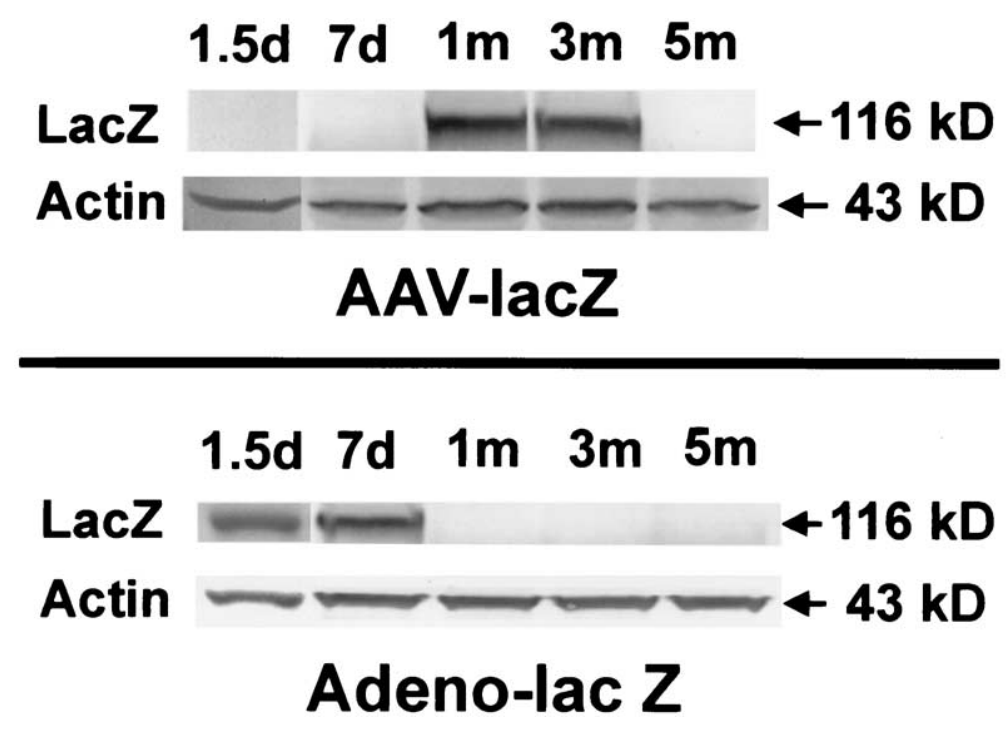

Figure 2. Western blots of $\beta$-galactosidase and actin filament protein expression from rat hearts at various time points after gene delivery. Actin, Actin filament protein; LacZ, $\beta$-galactosidase protein; $d$, day; $k D$, kilodalton; $m$, month; Adeno-lacZ, Adeno-lacZ-injected hearts; AAV-lacZ, AAV-lacZ-injected hearts.

over into other organs. In contrast, myocardial transduction with Adeno-lacZ consistently resulted in $\beta$-gal protein detection, by Western blot analysis, in both the heart and lungs. Macrophages in the lung were the principal cell type expressing the transgene. Although other studies using an intracoronary delivery of adenovirus have reported transgene expression in other organs such as the liver and testes, ${ }^{23}$ we did not find this pattern of expression in organs outside the chest using a direct myocardial injection route. We were unable to detect either AAV or adenoviral DNA in peripheral circulation of our injected animals by polymerase chain reaction at 10 minutes, 1 hour, 6 hours, and 24 hours after viral myocardial injection (data not shown), indicating this gene delivery technique did not result in systemic circulation of recombinant virus.

\section{Intramyocardial Injection of AAV Does Not Provoke} an Inflammatory Response

The amount of inflammation associated with intramyocardial injection of virus differed markedly between vectors. Direct intramyocardial injection of carrier alone resulted in minimal pathologic response with absence of acute cellular infiltrate at 7 days. However, by 1 month postinjection, fibrous tissue lined the needle track. Direct intramyocardial injection of AAV-lacZ was identical microscopically to sham injection at all time points, even when transgene expression was abundant (Figure 5). These appearances were in marked contrast to Adeno-lacZ, which caused significant inflammation with cellular infiltrate of lymphocytes, macrophages, monocytes at 36 hours and lymphocytes, macrophages, monocytes, and fibroblasts at day 7. At

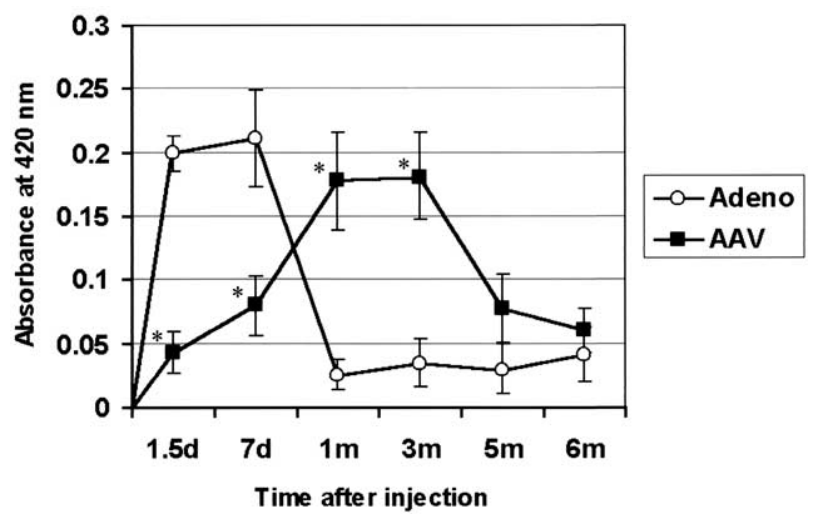

Figure 3. Beta-galactosidase activity assay of rat hearts after intramyocardial injection of AAV-lacZ or Adeno-lacZ at various time points. Data are expressed as the mean \pm standard error of the mean (SEM). ${ }^{*} P<.05$ versus Adeno-lacZ group. Adeno, Adeno-lacZ-injected hearts; AAV, AAV-lacZ-injected hearts; $d$, day; $m$, month; $n m$, nanometer.

1 month postinjection, the Adeno-lacZ hearts still had evidence of significant inflammatory infiltrate and fibrous scarring replacing previously viable myocytes.

\section{Comment}

This report presents a parallel comparison of 2 viral vectors currently used in gene therapy experiments. In a reproducible, systematic way, we compared the efficiency of viral transduction, spatial pattern of exogenous gene expression, and the duration of transgene protein expression in the in 


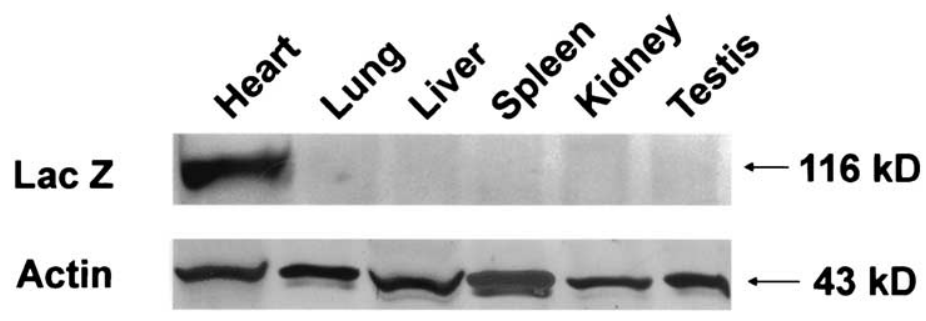

AAV-lacZ

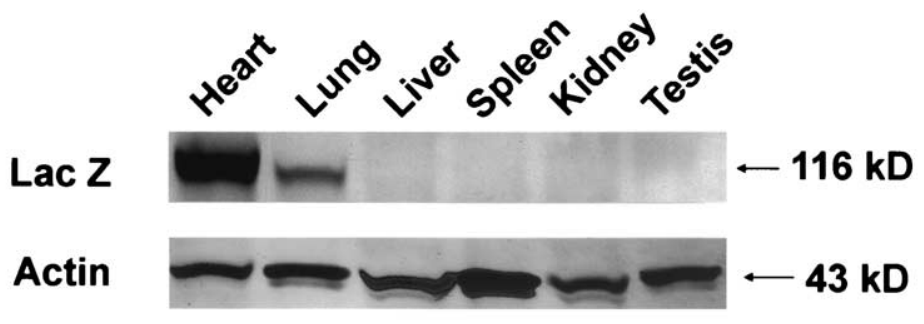

Adeno-lacZ

Figure 4. Western blots of $\beta$-galactosidase and actin filament protein expression from various rat organs 1 month after intramyocardial injection of AAV-lacZ and 7 days after intramyocardial injection of Adeno-lacZ. Actin, Actin filament protein; $k D$, kilodalton; $L a c Z, \beta$-galactosidase protein.

vivo rodent heart. Although there have been many reports about different viral vectors and their efficiency in other organs and in cultured myocytes, most have focused on a particular gene of interest and have been limited to 1 selected vector system.

Our goal is to explore and perfect new gene delivery systems available to effect long-term, site-specific gene expression in the mammalian heart. The premise for these experiments is that there have been few controlled studies published that directly compare one viral gene therapy system to another in in vivo myocardial models using a surgical approach. ${ }^{24,25} \mathrm{We}$ chose the direct intramyocardial injection route for gene delivery, because this method is uniquely available to the thoracic surgeon. We do not know whether direct myocardial injection, which limits transgene expression to a fixed area of the heart, is the most effective way to deliver genes to the myocardium, nor can we speculate whether this method will ultimately be effective for the treatment of human heart disease. In this report, we demonstrate efficient and stable transduction of cardiac myocytes in vivo up to 3 months after intramyocardial injection of an AAV-lacZ vector. Our results suggest that AAV has significant advantages compared with conventional adenovirus vectors in terms of longevity of gene expression and paucity of pathologic toxicity.
Several conclusions may be drawn from this set of experiments. First, pure high titer AAV vectors can be constructed, grown, and purified with relative ease using newer techniques published over the past year. ${ }^{21}$ Earlier AAV purification methods were prone to impurities (crude cell lysate preparations), low multiplicity of infection virus $\left(\mathrm{CsCl}_{2}\right.$ gradient centrifugation), or demanded a high level of technical expertise to recover high titer virus (iodixanol or HPLC purification). We currently use a modified, singlestep, heparin-column purification technique; elution dimunition of viral titer is avoided while allowing for high titer purification without helper adenovirus.

Second, transgene expression with AAV in the mammalian heart lasts on the order of months, and transduction efficiency is similar to that seen with adenovirus. Although AAV transgene expression was not apparent until 4 weeks after gene transfer, it was persistent for up to 3 months after transduction. Indeed, we demonstrated that $\beta$-gal protein expression and enzymatic activity was as strong at 3 months after gene transfer as it was at 4 weeks. This contrasts to the adenovirus system, where we found (like other groups) that expression peaked in the period of 36 hours to 7 days in the heart and then gradually diminished to the point of being undetectable by Western analysis or $\beta$-gal assay by 4 weeks. 


\section{Adeno $\quad$ AAV $\quad$ PBS}

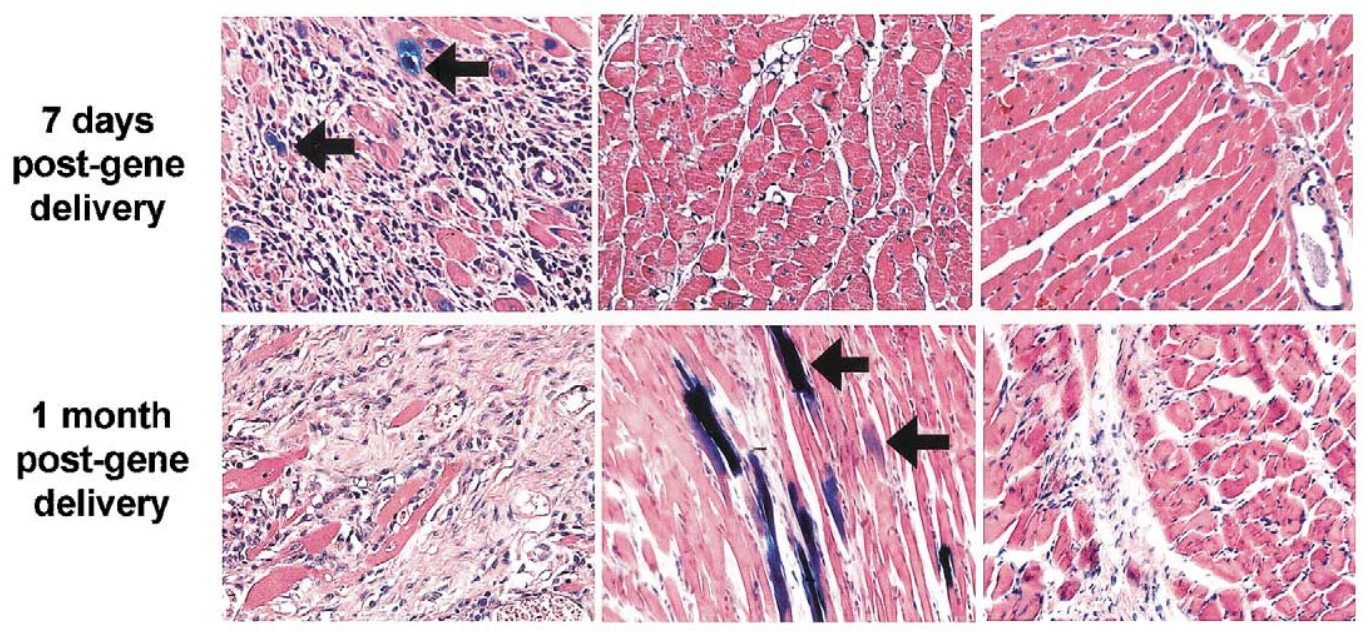

Figure 5. Photomicrographs of rat hearts at 7 days and 1 month after intramyocardial injection (hematoxylin and eosin stained, $X$-gal stained, magnification $\times 20$ ). Arrows denote examples of cardiomyocytes positive for $\beta$-galactosidase expression. Adeno, Adeno-lacZ-injected heart; AAV, AAV-lacZ-injected heart; PBS, phosphatebuffered saline-injected heart.

Third, AAV transgene expression is limited to the heart and cannot be detected in other organs after intramyocardial injection, whereas adenovirus transgene expression was detected in low amounts in both heart and lung. We believe that the severe inflammatory response associated with adenovirus transduction of the heart results in the local accumulation of macrophages and coinfection of this cell type. This tropism to cells other than myocytes after injection of the heart was seen only with adenovirus and not AAV. The fact that animals injected with adenovirus had transgene expression in lung macrophages underscores the hypothesis that lack of organ specificity of transgene expression may be due to the dissemination of migratory, inflammatory-type cells. Although myocardial inflammation with adenovirus injection has been reported previously, ${ }^{24,26}$ the techniques of $\mathrm{CsCl}_{2}$ (which we used) and HPLC virus purification have been associated with significantly less myocardial inflammation than that seen in earlier studies. ${ }^{27,28}$ Since the viruses did not enter the systemic circulation, they were not detected in other organs, as has been found for intracoronary injection of viral vectors. ${ }^{23}$ Additionally, we found that injection of comparable viral titer, by the same investigator, in the same age and strain of rat resulted in comparable transgene transduction efficiencies for both adenovirus and AAV. This result was reproducible and was independent of viral stock preparation.

Last, although intramyocardial injection limited AAV infection to the heart, there is a relatively small perimeter of transgene spread at each site of injection. This technique allowed for precise targeting to a specific region of the heart, albeit a region for each injection of only $1.0 \mathrm{~cm}^{2}$. This result suggests that for use in larger animals or humans, multiple injections will be necessary to cover larger territories of myocardium.

Two important questions remain to be addressed with regard to AAV as an effective gene therapy tool: Why is the onset of transgene expression delayed and why does transgene expression abate around 5 months after gene transfer?

AAV is a single-stranded DNA virus that has to be converted into a double-stranded form before it can be transcriptionally active. In actively dividing cells, this process is thought to occur over a short time period due to the presence of cellular DNA polymerases. ${ }^{29}$ In nondividing cells (like cardiac myocytes), gene expression after injection of purified AAV occurs between 8 and 31 days later. The delay in transgene expression that we experienced with AAV is presumably due to a time-dependent conversion to a transcriptionally active, double-stranded DNA intermediate. In contrast, another group has reported maximal transgene expression at days 3 to 5 with AAV in porcine and rat myocardium. ${ }^{16}$ We believe that, since viral preparation was based on a crude cell lysate in this report, early transgene expression was due to inadvertent transfer of contaminating helper virus or reporter protein, a phenomenon known as pseudotransfection. ${ }^{30}$

Finally, it is unclear why AAV gene expression is ultimately "lost" from the rodent heart around 5 months after gene transfer, whereas AAV skeletal muscle gene expression has been found to be still detectable at 1 year. ${ }^{13}$ Although we were able to detect lac $Z$ gene presence in the 
TABLE 1. Summary of direct intramyocardial injection of AAV

\begin{tabular}{|c|c|c|c|c|c|}
\hline First author & $\begin{array}{l}\text { Peak transgene } \\
\text { expression (wks) }\end{array}$ & $\begin{array}{l}\text { Last detected } \\
\text { transgene } \\
\text { expression } \\
\text { (wks) }\end{array}$ & Animal & $\begin{array}{l}\text { No. of animals at } \\
\text { last time point }\end{array}$ & Gene \\
\hline Kaplitt, 1996 & NR & $8^{*}$ & Sprague-Dawley rats & NR & lacZ \\
\hline Lee, 1999 & NR & $24^{*}, \dagger$ & Sprague-Dawley rats & 3 & Thrombopoietin \\
\hline Svensson, 1999 & 4 & $8^{*}$ & CD-1 mice & 3 & lacZ \\
\hline Su, 2000 & NR & $12^{*}$ & CD-1 mice & 2 & lacZ/VEGF \\
\hline Kawada, 2001 & NR & $20^{*}$ & TO-2 hamsters & 6 & $\operatorname{lacZ} / \delta-S G 1$ \\
\hline Kimura, 2001 & NR & $14^{*}$ & $\mathrm{SH}$ rats & 10 & $\begin{array}{l}\text { GFP/angiotensin } \\
\text { antisense }\end{array}$ \\
\hline Wright, 2001 & 3 & 3 & New Zealand White rabbits & 4 & lacZ \\
\hline Kawada, 2002 & NR & $35^{*}$ & TO-2 hamsters & 10 & $\operatorname{lacZ/\delta -SG1}$ \\
\hline Melo, 2002 & NR & $10^{*}$ & Sprague-Dawley rats & 6 & lacZ/hHO-1 \\
\hline
\end{tabular}

$\delta$-SG1, $\delta$-Sarcoglycan1; GFP, green fluorescent protein; $h H O-1$, human heme oxygenase-1; NR, not recorded; SH, spontaneously hypertensive; VEGF, vascular endothelial growth factor.

*Experiments terminated at this time point.

†Transgene not assayed. Platelet level of animals measured as clinical response to presumed transgene expression.

heart by Southern blot analysis 6 months after gene transfer, this gene was not detected as a transcribed or translated product at this time interval, suggesting that chromatin remodeling may play a role in long-term expression of foreign genes incorporated into the host genome. We have reviewed all published gene therapy experiments performed with direct myocardial injection of AAV irrespective of transgene (Table 1). ${ }^{16,17,24,25,31-35}$ Although these reports suggest a transgene expression window ranging from 2 to 4 months, most studies terminate when transgene expression is still detected and do not necessarily represent the longterm natural history of this vector in the heart. Modification of virus by serotype selection, genetic manipulation of virion coat protein tropism, and better understanding of the kinetics of viral DNA integration may lead to higher titer, permanent AAV transduction in the heart.

In summary, despite these caveats, our results suggest that AAV vectors have significant advantage over adenovirus vectors for stable, long-term expression of recombinant genes in cardiomyocytes in vivo, and, as such, may represent the future vehicle for the treatment of many forms of cardiac disease.

We thank Dr. R. Jude Samulski for gifts of cotransfecting plasmids pXX2 and pXX6. We also thank Paul Shragg, MA, Biostatistics, for statistical analysis of the study data.

\section{References}

1. Vale PR, Losordo DW, Milliken CE, McDonald MC, Gravelin LM, Curry CM, et al. Randomized, single-blind, placebo-controlled pilot study of catheter-based myocardial gene transfer for therapeutic angiogenesis using left ventricular electromechanical mapping in patients with chronic myocardial ischemia. Circulation. 2001;103:213843.

2. Giordano FJ, Ping P, McKirnan D, Nozaki S, DeMaria AN, Dillmann $\mathrm{WH}$, et al. Intracoronary gene transfer of fibroblast growth factor-5 increases blood flow and contractile function in an ischemic region of the heart. Nat Med. 1996;2:534-9.

3. Byun J, Huh JE, Park SJ, Jang JE, Suh YL, Lee JS, et al. Myocardial injury-induced fibroblast proliferation facilitates retroviral-mediated gene transfer to the rat heart in vivo. J Gene Med. 2000;2:2-10.

4. Coffin RS, Howard MK, Cumming DV, Dollery CM, McEwan J, Yellon DM, et al. Gene delivery to the heart in vivo and to cardiac myocytes and vascular smooth muscle cells in vitro using herpes virus vectors. Gene Ther. 1996;3:560-6.

5. Morral N, O'Neal W, Rice K, Leland K, Kaplan J, Piedra PA, et al. Administration of helper-dependent adenoviral vectors and sequential delivery of different vector serotype for long-term liver-directed gene transfer in baboons. Proc Natl Acad Sci U S A. 1999;96:12816-21.

6. Jayakumar J, Suzuki K, Sammut IA, Smolenski RT, Khan M, Latif N, et al. Heat shock protein 70 gene transfection protects mitochondrial and ventricular function against ischemia-reperfusion injury. Circulation. 2001;104(12 Suppl 1):I303-7.

7. Hammond HK, McKirnan MD. Angiogenic gene therapy for heart disease: a review of animal studies and clinical trials. Cardiovasc Res. 2001;49:561-7.

8. Rosengart TK, Lee LY, Patel SR, Sanborn TA, Parikh M, Bergman $\mathrm{GW}$, et al. Angiogenesis gene therapy: phase I assessment of direct intramyocardial administration of an adenovirus vector expressing VEGF121 cDNA to individuals with clinically significant severe coronary artery disease. Circulation. 1999;100:468-74.

9. Muhlhauser J, Jones M, Yamada I, Cirielli C, Lemarchand P, Gloe TR, et al. Safety and efficacy of in vivo gene transfer into the porcine heart with replication-deficient, recombinant adenovirus vectors. Gene Ther. 1996;3:145-53.

10. Chirmule N, Moscioni AD, Qian Y, Qian R, Chen Y, Wilson JM. Fas-Fas ligand interactions play a major role in effector functions of cytotoxic T lymphocytes after adenovirus vector-mediated gene transfer. Hum Gene Ther. 1999;10:259-69.

11. Flotte TR, Carter BJ. Adeno-associated virus vectors for gene therapy. Gene Ther. 1995;2:357-62.

12. Nakai H, Yant SR, Storm TA, Fuess S, Meuse L, Kay MA. Extrachromosomal recombinant adeno-associated virus vector genomes are primarily responsible for stable liver transduction in vivo. $J$ Virol. 2001;75:6969-76.

13. Xiao X, Li J, Samulski RJ. Efficient long-term gene transfer into muscle tissue of immunocompetent mice by adeno-associated virus vector. J Virol. 1996;70:8098-108.

14. Flannery JG, Zolotukhin S, Vaquero MI, LaVail MM, Muzyczka N, Hauswirth WW. Efficient photoreceptor-targeted gene expression in 
vivo by recombinant adeno-associated virus. Proc Natl Acad Sci U S A. 1997;94:6916-21.

15. Fu H, Samulski RJ, McCown TJ, Picornell YJ, Fletcher D, Muenzer J. Neurological correction of lysosomal storage in a mucopolysaccharidosis IIIB mouse model by adeno-associated virus-mediated gene delivery. Mol Ther. 2002;5:42-9.

16. Kaplitt MG, Xiao X, Samulski RJ, Li J, Ojamaa K, Klein IL, et al. Long-term gene transfer in porcine myocardium after coronary infusion of an adeno-associated virus vector. Ann Thorac Surg. 1996;62: 1669-76.

17. Wright MJ, Wightman LM, Lilley C, de Alwis M, Hart SL, Miller A, et al. In vivo myocardial gene transfer: optimization, evaluation and direct comparison of gene transfer vectors. Basic Res Cardiol. 2001; 96:227-36.

18. Maeda Y, Ikeda U, Shimpo M, Ueno S, Ogasawara Y, Urabe M, et al. Efficient gene transfer into cardiac myocytes using adeno-associated virus (AAV) vectors. J Mol Cell Cardiol. 1998;30:1341-8.

19. Giordano FJ, He H, McDonough P, Meyer M, Sayen MR, Dillmann WH. Adenovirus-mediated gene transfer reconstitutes depressed sarcoplasmic reticulum $\mathrm{Ca}^{2+}$-ATPase levels and shortens prolonged cardiac myocyte $\mathrm{Ca}^{2+}$ transients. Circulation. 1997;96:400-3.

20. Xiao X, Li J, Samulski RJ. Production of high-titer recombinant adeno-associated virus vectors in the absence of helper adenovirus. J Virol. 1998;72:2224-32.

21. Auricchio A, Hildinger M, O'Connor E, Gao GP, Wilson JM. Isolation of highly infectious and pure adeno-associated virus type 2 vectors with a single-step gravity-flow column. Hum Gene Ther. 2001;12: 71-6.

22. Thistlethwaite PA, Lee SH, Du LL, Wolf PL, Sullivan C, Pradhan S, et al. Human angiopoietin gene expression is a marker for severity of pulmonary hypertension in patients undergoing pulmonary thromboendarterectomy. J Thorac Cardiovasc Surg. 2001;122:65-73.

23. Barr E, Carroll J, Kalynych AM, Tripathy SK, Kozarsky K, Wison JM, et al. Efficient catheter-mediated gene transfer into the heart using replication-defective adenovirus. Gene Ther. 1994;1:51-8.

24. Svensson EC, Marshall DJ, Woodard K, Lin H, Jiang F, Chu L, et al. Efficient and stable transduction of cardiomyocytes after intramyocardial injection or intracoronary perfusion with recombinant adenoassociated virus vectors. Circulation. 1999;99:201-5.

25. Lee LY, Zhou X, Polce DR, El-Sawy T, Patel SR, Thakker GD, et al. Exogenous control of cardiac gene therapy: evidence of regulated myocardial transgene expression after adenovirus and adeno-associ- ated virus transfer of expression cassettes containing corticosteroid response element promoters. J Thorac Cardiovasc Surg. 1999;118:2635 .

26. French BA, Mazur W, Geske RS, Bolli R. Direct in vivo gene transfer into porcine myocardium using replication-deficient adenoviral vectors. Circulation. 1994;90:2414-24.

27. Patel SR, Lee LY, Mack CA, Polce DR, El-Sawy T, Hackett NR, et al. Safety of direct myocardial administration of an adenovirus vector encoding vascular endothelial growth factor 121. Hum Gene Ther. 1999;10:1331-48.

28. Chan SY, Li K, Piccotti JR, Louie MC, Judge TA, Turka LA, et al. Tissue-specific consequences of the anti-adenoviral immune response: implications for cardiac transplants. Nat Med. 1999;5:1143-9.

29. Fisher KJ, Gao GP, Weitzman MD, DeMatteo R, Burda JF, Wilson JM. Transduction with recombinant adeno-associated virus for gene therapy is limited by leading-strand synthesis. J Virol. 1996;70:52032.

30. Alexander IE, Russell DW, Miller AD. Transfer of contaminants in adeno-associated virus vector stocks can mimic transduction and lead to artifactual results. Hum Gen Ther. 1997;8:1911-20.

31. Su H, Lu R, Kan YW. Adeno-associated viral vector-mediated vascular endothelial growth factor gene transfer induces neovascular formation in ischemic heart. Proc Natl Acad Sci U S A. 2000;97:13801-6.

32. Kawada T, Sakamoto A, Nakazawa M, Urabe M, Masuda F, Hemmi $\mathrm{C}$, et al. Morphological and physiological restorations of hereditary form of dilated cardiomyopathy by somatic gene therapy. Biochem Biophys Res Commun. 2001;284:431-5.

33. Kimura B, Mohuczy D, Tang X, Phillips MI. Attenuation of hypertension and heart hypertrophy by adeno-associated virus delivering angiotensinogen antisense. Hypertension. 2001;37:376-80.

34. Kawada T, Nakazawa M, Nakauchi S, Yamazaki K, Shimamoto R, Urabe M, et al. Rescue of hereditary form of dilated cardiomyopathy by rAAV-mediated somatic gene therapy: amelioration of morphological findings, sarcolemmal permeability, cardiac performances, and the prognosis of TO-2 hamsters. Proc Natl Acad Sci U S A. 2002;99: 901-6.

35. Melo LG, Agrawal R, Zhang L, Rezvani M, Mangi AA, Ehsan A, et al. Gene therapy strategy for long-term myocardial protection using adeno-associated virus-mediated delivery of heme oxygenase gene. Circulation. 2002;105:602-7. 